\title{
DETERMINANT MODEL OF COMPANY VALUE WITH PROFITABILITY AS A MEDIATION VARIABLE
}

\author{
Roni Parlindungan Sipahutar ${ }^{1}$, M. Firza Alpi ${ }^{2}$, Baihaqi Ammy ${ }^{3}$ \\ ${ }^{1,2,3}$ Faculty of Economics and Business, Universitas Muhammadiyah Sumatera Utara \\ E-mail: ${ }^{1)}$ roniparlinsipahutar@gmail.com *. ${ }^{2)}$ m.firzaalpi@ umsu.ac.id, ${ }^{3)}$ baihaqiammy@ gmail.com
}

\begin{abstract}
This study aims in general to produce a determinant model of firm value with profitability as a mediating variable. The population in this study were all general pharmaceutical sector companies listed on the Indonesia Stock Exchange in 2013-2018. Sampling in this study used a census technique, which was to place the entire population into an observation sample. The sampling method used is purposive sampling with a total sample of 6 Pharmaceutical Companies Listed on the Indonesia Stock Exchange and data from 2013 - 2018. Data collection is carried out on the Indonesia Stock Exchange (IDX) with the website www.idx.co. en. Data analysis techniques in this study are descriptive statistics, multiple regression analysis and path analysis to test the mediating variables. The results of the study show that liquidity has a negative and significant effect on firm value. Meanwhile, profitability has no significant effect on firm value. The liquidity has a positive and significant effect on firm value with profitability as an intervention variable.
\end{abstract}

Keywords: Liquidity, Profitability, Firm Value.

\section{INTRODUCTION}

Competition in the pharmaceutical industry makes every pharmaceutical company improve its performance so that its goals can still be achieved. One of the goals is to maximize shareholder wealth through maximizing firm value. For companies that are still private or have not gone public, the value of the company is determined by an appraisal agency or an apprcial company. For companies that will go public, the value of the company can be indicated or implied from the number of variables attached to the company. For example, the assets owned by the company, management expertise in managing the company. Every company owner will always show potential investors that their company is the right investment alternative, so if the company owner is not able to display a good signal about the company's value, the value of the company will be above or below its true value. Meanwhile, the value of the company for a company that has gone public can be determined by the mechanism of supply and demand on the stock exchange, which is reflected in the listing price.

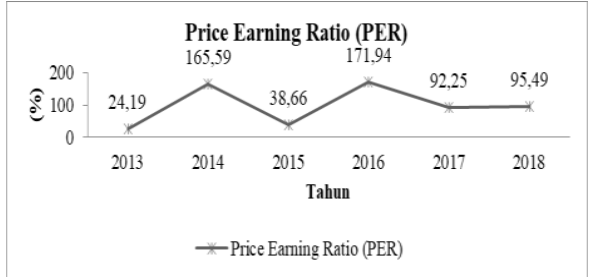

Figure 1 Graph of Average PER in Pharmaceutical Companies Listed on the IDX

In Figure 1, it is known that the average development of company value in 2013-2018, where the average development is price earning ratio (PER) decreased in 2015 by $38.66 \mathrm{x}$ and in 2017 by $92.25 \mathrm{x}$, from the previous year. The cause of the decline in the value of the company is due to declining profits, making it difficult for investors to reinvest shares and the management is not careful in applying the factors that can maximize the value of the company. These factors are liquidity and profitability. 
The current ratio is used to find the liquidity value. The better the company's ability to pay off its obligations, the smaller the risk of liquidation experienced by the company, it is important for investors to know the value of the current ratio even though this ratio is only temporary or short term. Investors will assume the company operates well and is able to cover its short-term obligations so that when the current ratio is good, the demand for company value will increase so that it will affect the value of the company. The liquidity ratio in this study uses the Current Ratio (CR).

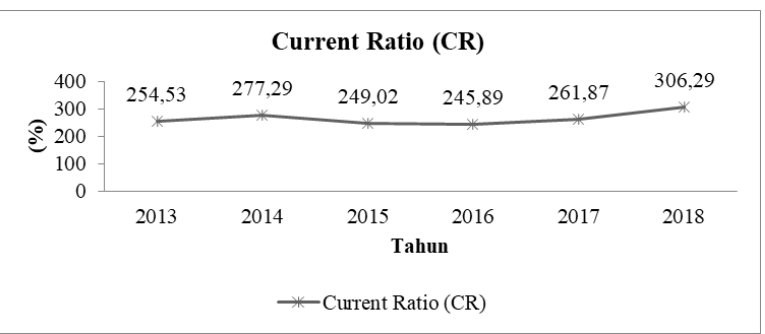

Figure 2 Graph of Average CR in Pharmaceutical Companies Listed on the IDX

In graph 1.2 above, it is known that the average development of the liquidity ratio in 20132018, where the average development is Current Ratio(CR) decreased in 2015 by $249.02 \%$ and in 2016 by $245.89 \%$, from the previous year. According to Mardiyanto (2013), "The profitability ratio is the company's ability to generate profits. The profitability ratio in this study uses return on assets (ROA). High ROA shows the company's ability to generate high profits for shareholders. A high ROA indicates the company's financial performance is good, so investors are interested in investing in the company in the form of shares. As a result, the demand for the shares offered increases, and in the end the value of the company also increases. A good number shows the success of the business the result is a high company value and makes it easier to attract new funds.

\section{IMPLEMENTATION METHOD}

This study uses a quantitative approach, namely by testing the associative relationship of measurable (parametric) research variables. The population of this study is all general pharmaceutical sector companies listed on the Indonesia Stock Exchange in 2013-2018. Sampling in this study using a census technique, which puts the entire population into an observation sample. Sampling using purposive sampling method is done by taking samples from the population based on certain criteria. The criteria set by the author are as follows:

a. Pharmaceutical Company listed on the Indonesia Stock Exchange (2013-2018).

b. Companies that publish audited financial statements during the observation period (2013-2018).

c. Companies that were not delisted from the IDX during the observation period (2013-2018).

d. Companies that issue financial statements in rupiah during the period (2013-2018).

e. Companies that have complete data related to research variables.

The sampling technique is based on purposive sampling, namely the technique of determining the sample with the considerations or criteria mentioned above.

Table 1 Research Sample

\begin{tabular}{|c|c|c|c|c|c|c|c|c|}
\hline \multirow{2}{*}{ No } & \multirow{2}{*}{ Code } & \multirow{2}{*}{ Issuer Name } & \multicolumn{5}{|c|}{ Criteria } & \multirow{2}{*}{ Sample } \\
\hline & & & 1 & 2 & 3 & 4 & 5 & \\
\hline 1 & DVLA & Darya Varia Laboratoria Tbk & $\square$ & $\square$ & $\square$ & $\square$ & $\square$ & 1 \\
\hline 2 & INAF & Indofarma (Persero) Tbk & $\square$ & $\square$ & $\square$ & $\square$ & $\square$ & 2 \\
\hline 3 & KAEF & Kimia Farma (Persero) Tbk & $\square$ & $\square$ & $\square$ & $\square$ & $\square$ & 3 \\
\hline 4 & KLBF & Kalbe Farma Tbk & $\square$ & $\square$ & $\square$ & $\square$ & $\square$ & 4 \\
\hline 5 & BRAND & Merck Indonesia Tbk & $\square$ & $\mathrm{X}$ & $\square$ & $\square$ & $\mathrm{X}$ & $\mathrm{X}$ \\
\hline 6 & PYFA & Pyridam Farma Tbk & $\square$ & $\square$ & $\square$ & $\square$ & $\square$ & 5 \\
\hline
\end{tabular}




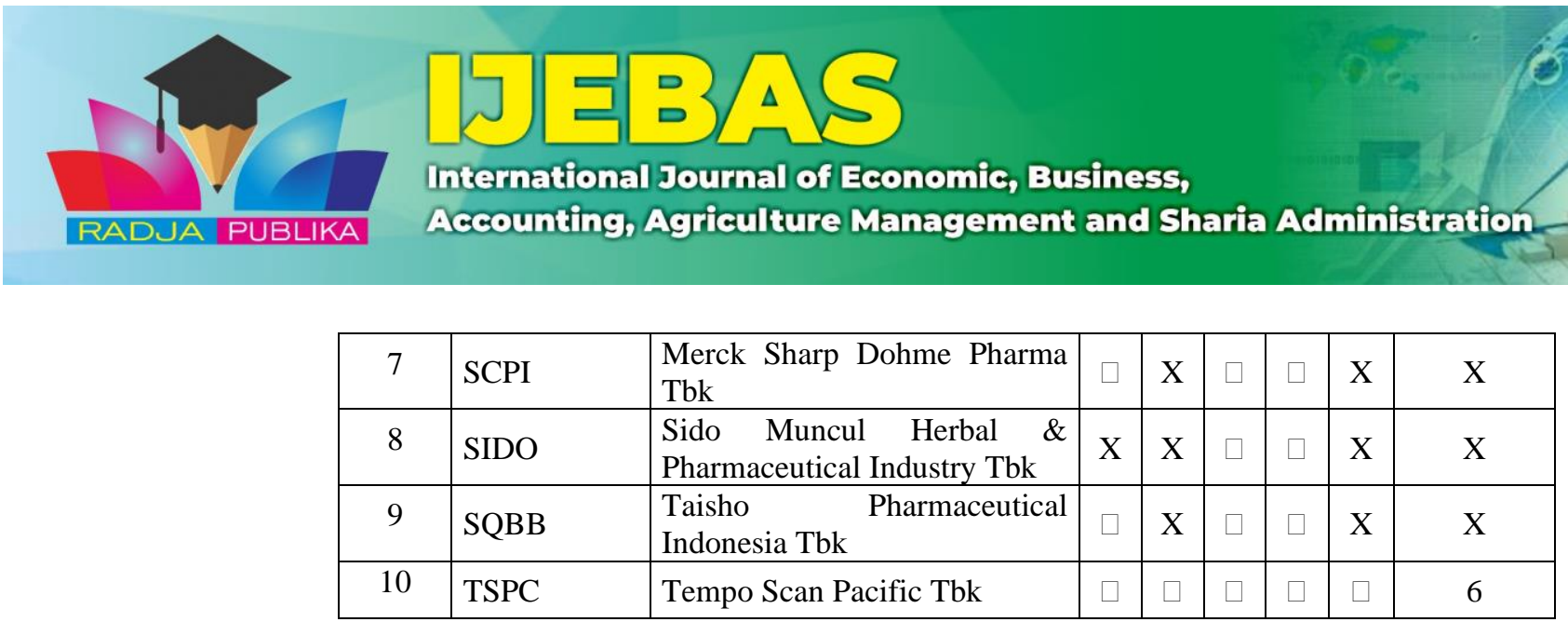

Based on these criteria, the authors set as many as 6 samples of companies that are included in the research sample data.

Path analysis is also used to determine the direct and indirect effects of the observed variables. The path diagram depicting the pattern of relationships between variables in this study is a test to find out how much influence liquidity has on firm value with profitability as the intervening variable with the equation:

Equation $\mathrm{I}: \mathrm{Z}=\mathrm{P} 1 \mathrm{X}+€ 1$

Equation II : $\mathrm{Y}=\mathrm{P} 3 \mathrm{X}+\mathrm{P} 2 \mathrm{Z}+€ 2$

Information:

$\mathrm{X}=$ Liquidity (Exogenous Variable)

$\mathrm{Z}=$ Profitability (Intervening Variable)

$\mathrm{Y}=$ Firm Value (Endogenous Variable)

$\mathrm{P}=$ Path Regression Coefficient

$€=$ Number of variants $(€=1-\mathrm{R} 2)$

\section{RESULTS AND DISCUSSION}

\subsection{Research result}

\subsubsection{Classic assumption test}

The classical assumption test used in this study includes normality test, multicollinearity test, autocorrelation test, and heteroscedasticity test.

\subsubsection{Normality Test}

Testing with the Kolmogorov-Smirnov test method is used to determine the results of the normality of research data whose results can be seen in the table below:

Table 2 Normality Test Path 1

One-Sample Kolmogorov-Smirnov Test

\begin{tabular}{|ll|r|}
\hline & & \multicolumn{1}{|c|}{$\begin{array}{c}\text { Unstandardized } \\
\text { Residual }\end{array}$} \\
\hline $\mathrm{N}$ & mean & 30 \\
Normal Parameters, b & Std. & .0000000 \\
& Deviation & .04389758 \\
& Absolute & .204 \\
Most Extreme Differences & Positive & .204 \\
& negative & -107 \\
Kolmogorov-Smirnov Z & & .920 \\
asymp. Sig. (2-tailed) & & .347 \\
\hline
\end{tabular}

a. Test distribution is Normal.

b. Calculated from data. 
From the results of the one sample Kolmogorov-Smirnov test, it can be seen that the asymp value. Sig has a value of $0.347>0.05$. So the data used in this study has met the requirements of the normality test or all data are normally distributed.

Table 3 Normality Test Path 2

One-Sample Kolmogorov-Smirnov Test

\begin{tabular}{|c|c|}
\hline & $\begin{array}{l}\text { Unstandardized } \\
\text { Residual }\end{array}$ \\
\hline $\begin{array}{ll}\text { N } & \text { mean } \\
\text { Normal Parameters, } & \begin{array}{l}\text { Std. Deviation } \\
\text { Absolute }\end{array} \\
\text { Most Extreme Differences } & \begin{array}{l}\text { Positive } \\
\text { negative }\end{array} \\
\text { Kolmogorov-Smirnov Z } & \\
\text { asymp. Sig. (2-tailed) } & \end{array}$ & $\begin{array}{r}30 \\
.0000000 \\
.04389758 \\
.204 \\
.204 \\
-107 \\
.920 \\
.347\end{array}$ \\
\hline
\end{tabular}

From the results of the one sample Kolmogorov-Smirnov test, it can be seen that the asymp value. Sig has a value of $0.233>0.05$. So the data used in this study has met the requirements of the normality test or all data are normally distributed.

\subsubsection{Multicollinearity Test}

Multicollinearity testing was carried out using the Variance Inflation Factor (VIF). The data is said to have no multicollinearity if the Tolerance value 0.10 and the VIF value 10 . The results of the multicollinearity test can be seen in Table 4:

Table 4 Multicollinearity Test Path 1

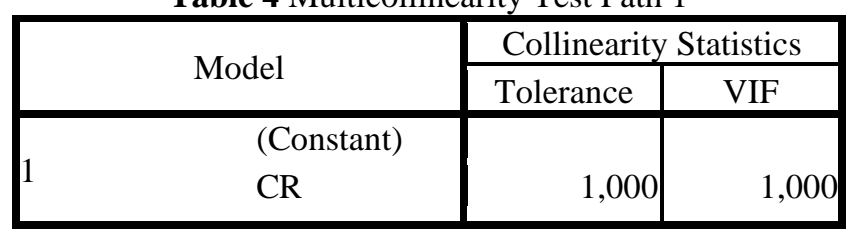

Based on the table above, it is known that the value of Tolerance 0.10 and VIF $<<10$, so it can be concluded that the research data does not have multicollinearity symptoms.

Table 5 Multicollinearity Test Path 2

\begin{tabular}{|ll|r|r|}
\hline \multirow{2}{*}{ Model } & \multicolumn{3}{l|}{ Collinearity Statistics } \\
\cline { 3 - 4 } & & Tolerance & VIF \\
\hline \multirow{3}{*}{1} & (Constant) & & \\
& CR & .810 & 1.214 \\
& ROA & .810 & 1.214 \\
\hline
\end{tabular}

Based on Table 5 shows that all independent variables have a Tolerance 0.10 and a VIF value 10 so that the research data does not experience multicollinearity.

\subsubsection{Heteroscedasticity Test}

A good regression model is one with homoscedasticity or no heteroscedasticity. This test was carried out using a scatterplot graph analysis between the predicted value of the ZPRED dependent variable and the residual SPRESID. From the scatterplot graph, it can be seen that the points spread 


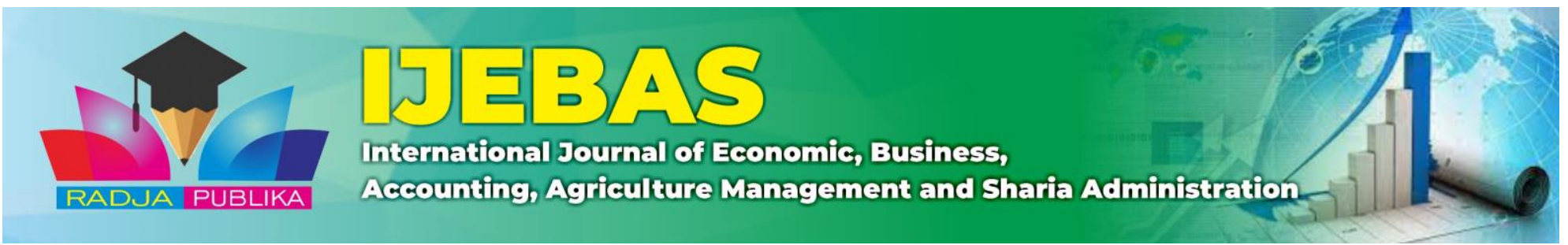

randomly above and below the number 0 on the $\mathrm{Y}$ axis. It can be concluded that there is no heteroscedasticity in the regression model (Ghozali, 2012). The scatterplot of this research can be shown in Figure 3 below:

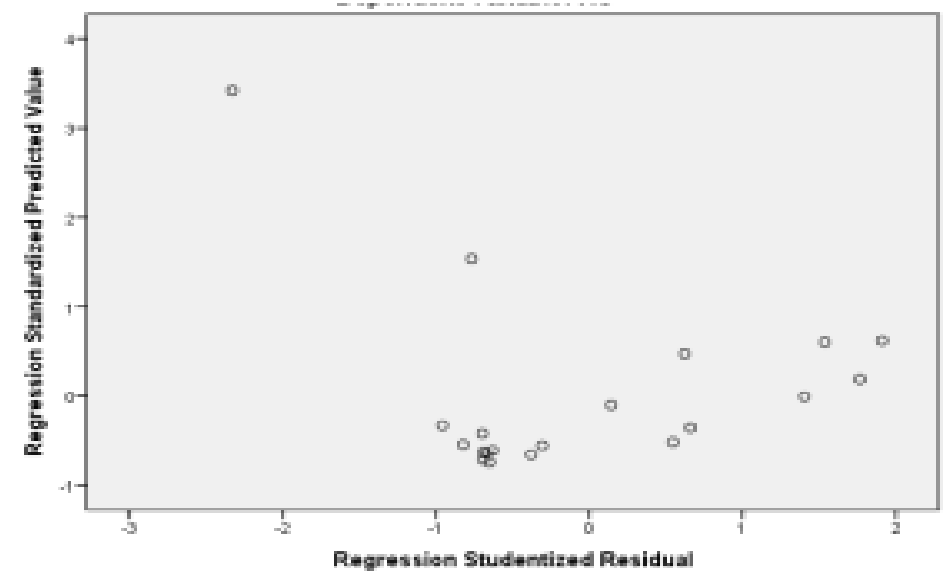

Figure 3 Pathway 1 . Heteroscedasticity Test

Based on the picture above, it can be seen that the points spread randomly, it can be stated that there is no heteroscedasticity problem.

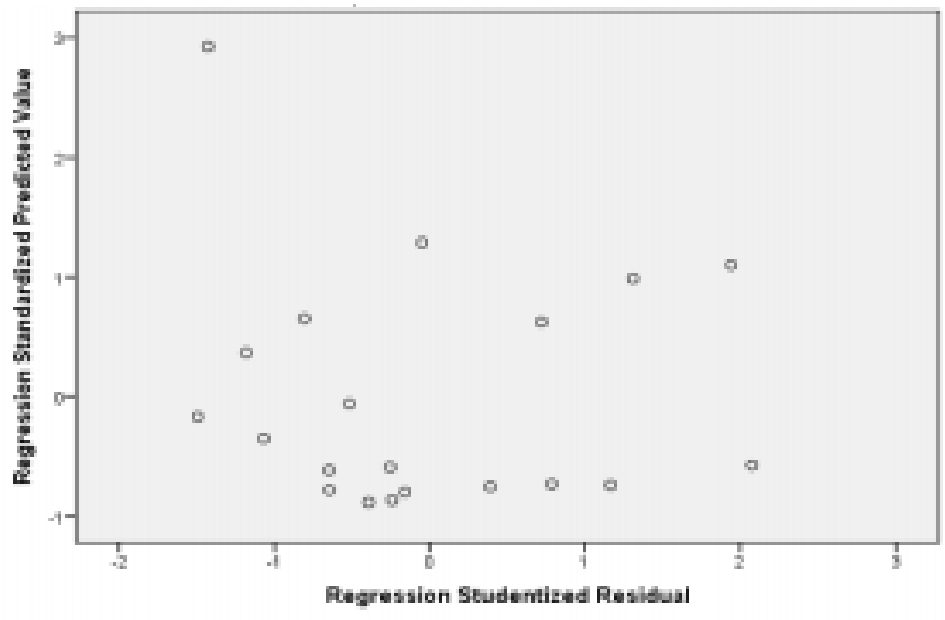

Figure 4 Pathway 2 . Heteroscedasticity Test

Based on the picture above, it can be seen that the points spread randomly, it can be stated that there is no heteroscedasticity problem.

\subsubsection{Autocorrelation Test}

The statistical value of the Durbin-Watson test ranged between 0 and 4. Statistical values of the Durbin-Watson test that were smaller than 1 or greater than 3 indicated an autocorrelation.

Table 6 Autocorrelation Test Path 1

\begin{tabular}{|l|r|}
\hline \multicolumn{1}{|c|}{ Model } & Durbin-Watson \\
\hline 1 & 1.865 \\
\hline
\end{tabular}


The value of the Durbin-Watson statistic is 1.865 . Note that since the Durbin-Watson statistic is between 1 and 3, i.e. $1<1.865<3$, the non-autocorrelation assumption is met. In other words, there is no high autocorrelation symptom in the residuals.

Table 7 Autocorrelation Test Path 2

\begin{tabular}{|l|lr|}
\hline \multicolumn{2}{|c|}{ Model } & \multicolumn{2}{|c|}{ Durbin-Watson } \\
\hline 1 & & 1,844 \\
\hline
\end{tabular}

Based on Table 5.5, the value of the Durbin-Watson statistic is 1.844 . Note that since the Durbin-Watson statistic is between 1 and 3, i.e. $1<1.844<3$, the non-autocorrelation assumption is met. In other words, there is no high autocorrelation symptom in the residuals.

\subsubsection{Path Analysis}

Path analysis is a development of multiple linear regression analysis. Each path tested, shows a direct effect (direct effect) or indirect (indirect effect) on. The following are the results of the path analysis in this study:

Path analysis is a development of multiple linear regression analysis. Each path tested, shows a direct effect (direct effect) or indirect (indirect effect) on. The following are the results of the path analysis in this study:

Table 8 Path Analysis Results

\begin{tabular}{|l|l|r|r|r|}
\hline $\begin{array}{c}\text { Independent } \\
\text { Variable }\end{array}$ & $\begin{array}{l}\text { Dependent } \\
\text { variable }\end{array}$ & \multicolumn{1}{c|}{$\mathrm{t}$} & \multicolumn{1}{c|}{ Sig. } \\
\hline CR & PBV & -0.880 & -2.271 & 0.026 \\
\hline ROA & PBV & 0.136 & 0.775 & 0.440 \\
\hline CR & $\begin{array}{l}\text { PBV via } \\
\text { ROA }\end{array}$ & 0.749 & 3.340 & 0.001 \\
\hline
\end{tabular}

Based on the results of the path analysis in table 8 , it can be explained that:

1. Effect of Liquidity on Firm Value. The unstandardized coefficient beta current ratio is -0.880 , the $\mathrm{t}$ value is -2.271 and the significance is 0.026 (less than 0.05 ), which means that liquidity has a significant effect on firm value.

2. The Effect of Profitability on Firm Value. The unstandardized coefficient beta return on assets is 0.136 , the $t$-value is 0.775 and the significance is 0.440 (greater than 0.05 ), which means that profitability has no significant effect on firm value.

3. Effect of Liquidity on Firm Value through Profitability. The unstandardized coefficient beta current ratio is 0.749 , the t-value is 3.340 and the significance is 0.001 (less than 0.05 ), which means that liquidity has a significant effect on firm value through profitability.

The results of the path analysis can be described as follows:

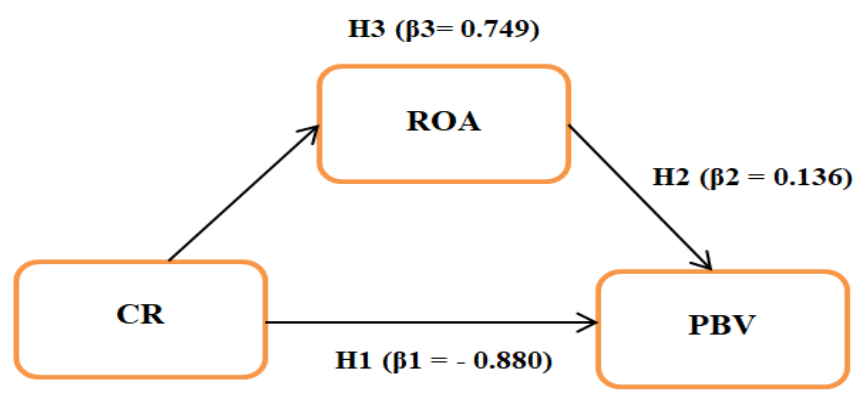

Figure 5 Path Analysis 
The next step is to calculate the path of influence of the liquidity variable directly (direct effect) or indirectly (indirect effect) on firm value through profitability as an intervening variable. The results of direct and indirect effects on this study are presented in the following table:

Table 9 Direct and Indirect Effects

\begin{tabular}{|l|r|r|r|}
\hline \multicolumn{1}{|c|}{ Information } & $\begin{array}{c}\text { Direct } \\
\text { Influence }\end{array}$ & $\begin{array}{c}\text { Indirect } \\
\text { Influence }\end{array}$ & $\begin{array}{c}\text { Total } \\
\text { Influence }\end{array}$ \\
\hline CR to PBV & -0.880 & -0.880 & \\
\hline ROA to PBV & 0.136 & 0.136 & \\
\hline CR to PBV via ROA & 0.749 & -0.65912 & -1.53912 \\
\hline
\end{tabular}

The direct effect for testing the path coefficient between CR and PBV is -0.880 . While the indirect effect of CR on PBV through ROA is $(0.749) \times(-0.880)=-0.65912$. So the total effect of the current ratio on price to book value $=(-0.880)+(-0.65912)=-1.53912$. The magnitude of the coefficient of indirect influence is greater than the coefficient of direct influence, it can be concluded that profitability can mediate the effect of liquidity on firm value.

\subsection{Discussion}

\subsubsection{Effect of Liquidity on Firm Value}

The first hypothesis in this study is that liquidity has a significant effect on price to book value. Based on the results of statistical tests obtained regression coefficient of -0.880 and a significance of 0.026 (less than 0.05). Based on these results, it can be concluded that liquidity has a significant effect on firm value. This means that the company's level of optimism in paying off its short-term debt will have an impact on its ability to create value for shareholders as reflected in price to book value. If the amount of short-term debt decreases, it will increase the price to book value. A high current ratio value indicates the value of current assets is greater than the value of current debt, This means that the company's receivables decrease so that more funds are available in the company to finance its operations and investments. If the current ratio is too high, it will have a negative impact on companies in the consumer goods industry for the period 2014-2018 because it means that the company has excess current assets that are unemployed.

The results of this study are in accordance with the theory of Hanafi and Halim (2003) which states that a current ratio that is too high indicates an excess of unemployed current assets. So it is not good for the company's profitability because current assets generate lower returns than fixed assets. Investors pay more attention to long-term ratios which have more value in return on investment than short-term ratios. This can reduce the value of the company because investors are reluctant to invest in companies with low returns, so it can mean that any increase in the current ratio of companies in the pharmaceutical industry sector will have an impact on the value of the company which is reflected in the price to book value. Therefore,

Business administration is an administrative activity in a profit-oriented business organization (company) or that uses profit as an indicator of the efficiency of its operations. According to Poerwanto (2016) administration has two functions, namely determining the overall goals to be achieved and determining general policies that bind the entire organization. If it is related to the results of this study, it is important for pharmaceutical industry sector companies to optimize their administrative activities for controlling and evaluating company performance so that company goals can be achieved and facilitate decision making, which will also have an impact on shareholder assessment of the company. Shareholders measure the company's operational efficiency through the achievement of profits. 


\subsubsection{The Effect of Profitability on Firm Value}

Based on the results of statistical tests, the regression coefficient was 0.136 and the significance was 0.440 (greater than 0.05). Based on these results, it can be concluded that profitability has no significant effect on firm value. That is, the level of success of the company in generating profits with all of its assets will have an impact on its ability to create value for shareholders which is reflected in price to book value. If the net profit after tax is higher, it will lead to high return optimism that will be obtained by shareholders.

This is supported by a statement from Prakoso (2016) which states that the greater the return on assets of a company, the greater the profits obtained and the better the position of the company in terms of asset use. The value of return on assets of consumer goods industry companies 2013-2017 has not been able to generate appropriate profits when compared to the total number of assets available in the company with a value of less than 1, this illustrates low profits for shareholders. So that the increase in profitability will not necessarily be followed by an increase in firm value.

If it is related to the results of this study, it is important for pharmaceutical industry sector companies to optimize their administrative activities for controlling and evaluating company performance so that company goals can be achieved and facilitate decision making, which will also have an impact on shareholder assessment of the company. Shareholders measure the company's operational efficiency through the achievement of profits. Often in business activities, investors compare the return on assets of a company with other similar companies which are its main competitors to determine the effectiveness of top management. This profitability ratio, known as the return on asset performance measure, is the main operating efficiency measure and the ratio that can be most controlled by the company's management.

Kasmir (2016) states that a high current ratio indicates that the company has placed large funds on the current asset side. The large placement of funds in current assets can cause the company's liquidity to improve and have an impact on the company's profitability. If the company's profitability increases, it means that the company's performance is good, causing increased investor confidence in the company to invest. So it can be said that the return on assets can interfere with the current ratio to the value of the company (price to book value).

If it is related to the results of this study, it is important for pharmaceutical sector companies to optimize their administrative activities for controlling and evaluating company performance so that company goals can be achieved and facilitate decision making, which will also have an impact on shareholder assessment of the company. Shareholders measure the company's operational efficiency through the achievement of profits, so it is appropriate to use profitability as an intervening variable in this study to measure the company's ability to generate profits in relation to knowing the company's ability to meet its short-term obligations (current ratio) which has an impact on how much the value of the company determined by the shareholders (price to book value).

\section{CONCLUSION}

From the research conducted, it can be concluded as follows:

1. Liquidity has a negative and significant effect on firm value

2. Profitability has no significant effect on firm value

3. Liquidity has a positive and significant effect on firm value with profitability as an intervening variable. 


\section{REFERENCES}

Barton, sidney L.,Ned C, Hill dan Sirnivasan Sundaran, (2014). "An EMPERICAL Test od Stakholder Theory Predictions of Capital Structure". Journal of the Financial Management Association, Spring.

Brigham, Eugene dan Joel F Houston, (2013). Manajemen Keuangan II. Jakarta:Salemba Empat.

Darmadji, Tjiptono dan Hendy M. Fakhruddin, 2016. Pasar Modal di Indonesia, Salemba Empat, Jakarta.

Erlina, 2013. Metodologi Penelitian, USU Press, Medan.

Evayanti, Sufratiwi, 2013. Analisis Pengaruh Faktor Fundamental Terhadap Harga Saham pada Perusahaan Basic Industry and Chemicals yang Terdaftar di Bursa Efek Indonesia, Skripsi, Fakultas Ekonomi Universitas Sumatera Utara.

Ghozali, Imam, 2015. Analisis Multivariat dengan Program SPSS, Edisi Ketiga, Badan Penerbit Universitas Diponegoro, Semarang.

Harahap, Sofyan Syafri, 2013. Analisis Kritis Atas Laporan Keuangan, PT Rajagrafindo Persada, Jakarta.

Harmono. (2017). Manajemen Keuangan. Berbasis Balanced Scorecard Pendekatan Teori, Kasus, dan Riset Penelitian.

Husnan, Suad. 2013. Dasar-dasar Teori Portofolio dan Analisis Securitas. Yogyakarta: UPP AMP YKPN

Indrawati, Titik dan Suhendro, 2016. "Determinasi Capital Structure pada Perusahaan Manufaktur di Bursa Efek Jakarta Periode 2000-2004”, Jurnal Akuntansi dan Keuangan Indonesia, Vol 3, No. 1 Januari-Juni, hal 77-105.

Indriyani, Eka. (2017). Pengaruh Ukuran Perusahaan dan Profitabilitas Terhadap Nilai Perusahaan.

Iramani, R. dan Erie Febrian. (2014). "Financial Value Added Suatu Paradigma Dalam Pengukuran Kinerja dan Nilai Tambah Perusahaan", JurnalAkuntansi dan Keuangan, Vol 7, No.1 Mei 2005: 1-10. Universitas Kristen Petra.Jakarta.

Jogiyanto, 2016. Teori Portofolio dan Analisis Investasi, BPFE, Yogyakarta.

Kasmir, (2015), Analisis Laporan Keuangan. Edisi Pertama. Rajawali Pers. Jakarta.

Kuncoro, Mudrajad, 2013. Metode Riset untuk Bisnis \& Ekonomi, Edisi 3, Erlangga, Jakarta.

Lubis, Ignatius Leonardus. (2017). Pengaruh Profitabilitas, Sruktur Modal, Dan Likuiditas Terhadap Nilai Perusahaan.

Mardiyanto, Handono, 2013. Intisari Manajemen Keuangan, PT Grasindo : Jakarta PT Grasindo.

Murni, Sri dan Andriana, 2015. "Pengaruh Insider Ownership, Institutional Investor, Devidend payment, dan Firm Growth terhadap Kebijakan Hutang Perusahaan (Studi Kasus pada Perusahaan Manufaktur yang terdaftar di Bursa Efek Jakarta)". Jurnal Akuntansi dan Bisnis, VOL. 7, No. 1, Februari, Hal. 15-24.

Riduwan (2013), Cara Menggunakan dan Memaknai Part Analysis (Analisis Jalur), Penerbit ALFABETA, Bandung.

Riyanto, Bambang, (2014). Dasar-dasar Pembelajaran Perusahaan, BPFE, Yogyakarta.

Sartono, Agus. (2013). Manajemen Keuangan Teori dan Aplikasi.Edisi ke Empat. BPFE, Yogyakarta.

Sawir, Agnes, (2014). Analisis Kinerja Keuangan dan Perencanaan Keuangan Perusahaan. Cetakan Kelima. PT. Gramedia Pustaka Utama. Jakarta.

Situmorang, Syafrizal Helmi dan Muslich Lufti, 2015. Analisis Data untuk Riset Manajemen dan Bisnis, USU Press, Medan.

Solfida, Eleonora. 2014. Pengaruh Ukuran Perusahaan Dan Karakteristik Kepemilikan Terhadap Harga Saham Pada Perusahaan LQ-45 Di Bursa Efek Jakarta, Tesis Program Magister Manajemen. Sekolah tinggi Ilmu Ekonomi Bisnis Indonesia.

Sugiyono, 2016. Metode Penelitian Bisnis, CV Alfabeta, Bandung. 
Determinant Model Of Company Value With Profitability As A Mediation Variable

DOI: $10.54443 /$ ijebas.v1i2.65

Suryaman, Yurian Ajie. (2016). Pengaruh Profitabilitas, Struktur Aktiva Dan Ukuran Perusahaan Terhadap Struktur Modal Pada Perusahaan Manufaktur Yang Terdaftar Di Bursa Efek Indonesia Tahun 2009-2012.

Sutrisno. (2014). Manajemen Keuangan Teori Konsep dan Aplikasi, Cetakan Ketujuh. Ekoisia.Yogyakarta.

Syamsuddin, Lukman. (2013). Manajemen Keuangan Perusahaan, PT. Raja Grafindo Persada, Jakarta.

Tandelilin, Eduardus, 2013. Portofolio dan Investasi Teori dan Aplikasi, Edisi Pertama, KANISIUS, Yogyakarta.

Walsh, Ciaran, 2016. Key Management Ratios, Edisi Keempat, Erlangga, Jakarta. 